\title{
Genética e linguagem na síndrome de Williams-Beuren: uma condição neuro-cognitiva peculiar****
}

\author{
Genetics and Language in Williams-Beuren Syndrome: a distinct \\ neurobehavioral disorder
}

\author{
Natalia Freitas Rossi * \\ Danilo Moretti-Ferreira** \\ Célia Maria Giacheti***
}

\section{* Fonoaudióloga. Doutoranda em Ciências Biológicas - Genética, pelo Instituto de Biociências da Universidade Estadual Paulista - Campus de Botucatu. Endereço para correspondência: Rua Jundiaí, 1215 - Matão - SP - CEP 15990-510 (nataliafreitasrossi@yahoo.com.br).}

**Biomédico. Doutor em Genética. Chefe do Serviço de Aconselhamento Genético e Docente do Instituto de Biociências do Departamento de Genética da Universidade Estadual Paulista - Campus de Botucatu.

***Fonoaudióloga. Doutora em Distúrbios da Comunicação. Docente do Departamento de Fonoaudiolgia da Faculdade de Ciências e Letras da Universidade Estadual Paulista Campus de Marília.

\section{****Parte da Dissertação de Mestrado do Primeiro Autor, Apresentada ao Programa de Pós-Graduação em Ciências Biológicas - Área de \\ Concentração: Genética do Instituto de Biociências da Universidade Estadual Paulista - Campus de Botucatu. Trabalho Realizado no Ambulátório de Fono-Genética do Serviço de Aconselhamento Genético do Instituto de Biociência da Universidade Estadual Paulista - Campus Botucatu, com Auxílio Financeiro do CNPq (Processo no 481111/04-2).}

\section{Revisão de Literatura}

Artigo Submetido a Avaliação por Pares

Conflito de Interesse: não

\begin{abstract}
Background: genetic, cognitive and language aspects of the Williams-Beuren Syndorme (WBS). Aim: to present a review of the literature about WBS, highlighting its genetic, cognitive and language characteristics. Conclusion: the literature indicates that although the etiology of WBS is known, early diagnosis is difficult due to the great variability of its clinical characteristics. This great phenotypic variability has been associated to a deletion of several genes in region 7q11.23 which includes the elastin gene. The deletion of this gene is identified by the Fluorecent in situ Hibridization test (FISH). The incidence of this syndrome is 1 in every 20,000 birth and is the result of a "de novo" genetic alteration. The syndrome is characterized by an elfin type face, cardiac alterations, cognitive deficits and behavioral aspects that include language. A peculiar cognitive profile has often been described as consisting of outstanding social and verbal skills associated to visuo-spatial impairments. Cognitive deficits are variable and may not be present. Studies that describe language abilities indicate that syntax might be intact or partially intact; speech can be precise and intelligible indicating that the phonological system is preserved. The receptive vocabulary is mentioned in a few studies as being adequate and in others as being impaired according to mental age. Researches have produced incongruent findings regarding the cognitive and linguistic abilities. The correlation between the language and cognitive abilities and the divergent findings presented in the literature will be discussed in this article. Key Words: Williams-Beuren Syndrome; Genetics; Cognition; Language.
\end{abstract}

\section{Resumo}

Tema: aspectos genéticos, cognitivos e de linguagem na Síndrome de Williams-Beuren (SWB). Objetivo: revisar a literatura sobre a SWB, destacando aspectos genéticos, cognitivos e de linguagem. Conclusões: a literatura mostrou que a etiologia da SWB é conhecida, embora o diagnóstico precoce pode ser difícil pela variabilidade de manifestações clínicas dessa condição. O fenótipo variável tem sido atribuído a deleção de vários genes na região 7q11.23. que inclui o gene da elastina. A deleção desse gene é identificada pelo estudo citogenético molecular denominado Hibridização in situ por Fluorescência (FISH). A freqüência populacional desta síndrome é de 1 em 20,000 nascimentos e é resultante de uma alteração genética "de novo". O quadro da SWB é caracterizado principalmente por fácies típica conhecida como face de duende, alterações cardíacas, prejuízos cognitivos e aspectos comportamentais que incluem a linguagem. A característica falante e sociável associada as dificuldades viso-construtivas conferem a esta síndrome um quadro neuro-cognitivo peculiar. A deficiência mental é variável e pode ou não estar presente. Estudos que descreveram as habilidades de linguagem nesta síndrome destacaram que a habilidade sintática pode estar íntegra ou parcialmente íntegra, a produção verbal pode ser precisa e inteligível, mostrando a integridade do sistema fonológico. O vocabulário receptivo-auditivo é citado em alguns estudos como adequado e em outros como prejudicado para a idade mental. Pesquisas na área têm produzido, resultados incongruentes com respeito ao perfil de habilidades cognitivas e lingüísticas nos portadores dessa condição. A correlação entre as habilidades de linguagem e a cognição e a divergência de achados na literatura serão abordadas neste artigo.

Palavras-Chave: Síndrome de Williams-Beuren; Genética; Cognição; Linguagem.

Recebido em 16.11.2005.

Revisado em 28.12.2005; 21.06.2006; 27.09.2006.

Aceito para Publicação 26.10.2006.

Referenciar este material como:

$\Omega$ ROSSI , N. F.; MORETTI-FERREIRA, D.; GIACHETI, C. M. Genetics and Language in Williams-Beuren Syndrome: a distinct neurobehavioral disorder (original

$\sum 3$ title: Genética e linguagem na síndrome de Williams-Beuren: uma condição neuro-cognitiva peculiar). Pró-Fono Revista de Atualização Científica, Barueri (SP), v. 18, n. 3, p.331-338, set.-dez. 2006. 


\section{Introduction}

Williams-Beuren syndrome(OMIM: 194050), first described by Williams et al. (1961) and Beuren et al. (1962), is a rare genetic disorder caused by a microdeletion of chromosome 7 . The clinical diagnosis is usually made on the basis of a distinctive face, cardiovascular malformations, idiopathic hypercalcemia, peculiar cognitive profile and language skills resultant from unusual personality and behavioral characteristics.

In Williams-Beuren syndrome (WBS), facial features include full cheeks, flat nasal bridge, long philtrum, periorbital fullness, wide mouth, full lips and anteverted ears. The most frequent cardiovascular abnormalities are supravalvular aortic stenosis and pulmonary arterial stenosis. Individuals with WBS frequently show mental retardation with impaired visuospatial skills and difficulties in language development/learning associated with an outgoing and expressive personality (MontgolfierAubron et al., 2000). The Williams Syndrome Cognitive Profile (WSCP) involves a clear strength in auditory rote memory, strength in language, and an extreme weakness in visuospatial construction relative to the overall level of intellectual ability, supporting the hypothesis that language and cognitive skills are dissociated in this syndrome (Pagon et al., 1987; Mervis and Klein-Tasman, 2000).

The purpose of this work was to review the literature on WBS with an emphasis on the genetic aspects of cognition and language.

\section{Etiology and diagnosis}

WBS is frequently of "de novo" origin and affects 1:20,000 livebirths (Borg et al., 1995). The term "de novo" is used to describe this syndrome as sporadic and of low risk of familial recurrence.

WBS is caused by the hemizygous microdeletion of approximately 20-25 genes on chromosome 7q11.23 (Figure 1A). Over 95\% of the individuals with WBS have deletion of the elastin gene (ELN) (Ewart et al., 1993) detectable by fluorescence in situ hybridization (FISH) (Figure 1B). Therefore, chromosome analysis and the Williams Syndrome Chromosome Region Fish Test are recommended for confirmation of the diagnosis.

However, a negative FISH result should not rule out WBS. The assessment of clinical signs and the use of molecular techniques more specific for the identification of other genes involved should also be taken into account when establishing the diagnosis.
In Brazil, the use of the FISH has been divulged, as associated disgnostic resource to the study of the clinical characteristics of the WBS, with the purpose to establish parameters for the request of this examination for the geneticist (Sugayama 2001; Souza, 2003).

\section{Clinical characteristics}

The WBS phenotype is characterized by cardiovascular abnormalities, typical facial features, unique cognitive profile, unusual personality, and language abilities. Very frequently, the presence of cardiac problems is the clinical sign that allows the early diagnosis of WBS because they can be identified at an early age. Approximately 75 to $80 \%$ of the individuals with WBS display cardiovascular disorders, particularly supravalvular aortic stenosis (65\% of the cases) and pulmonary artery sclerosis (38\% of the cases) (Sugayama et al., 2001).

The facial features typically observed in WBS individuals have given rise to different denominations to this disorder. One of them is Elfin Facies syndrome (Joseph and Parrot, 1958), given the presence of facial dysmorphisms such as upturned nose, flat nasal bridge, periorbital fullness, wide mouth, full lower lip, full cheeks, and long nasal philtrum

Other clinical characteristics could be find as: inguinal and umbilical hernia; stellate iris; harsh and hoarse voice; chronic otitis media; dental abnormalities; prenatal growth and weight deficiency and short stature. The poor weight gain is commom in the first years of life and is likely due to the severe difficulties with feeding and gastrointestinal problems (Pankau et al. 1994; Souza, 2003).

The literature reviewed included WBS clinical characteristics in patients with and without microdeletion of the ELN gene (Chart 1). The variation in the total number of cases shown in Table 1 is due to the fact that not all studies reviewed included all the characteristics below.

Visuospatial construction and verbal abilities: cognitive studies

Psychometric tests have revealed that, in WBS, Intelligence Quotient (IQ) ranges from 50 to 70 , i.e., mild to moderate mental retardation (Udwin et al., 1987; Bellugi et al., 1999) with poor visouspatial construction when compared to 
verbal ability, providing evidence for dissociation between these tasks (Udwin and Yule, 1991; Jarrold et al., 1999). However, some studies have shown that verbal and executive skills are equally impaired (Carrasco et al., 2005; Porter and Coltheart, 2005). The study of visuospatial processing has shown that WBS individuals have a preference to process the parts of an image at the expense of attending to the global form, suggesting that the ability to group visual stimuli may be affected (Jordan et al., 2002; Farran et al., 2003). The investigation of visual and spatial memory skills, either isolated or associated, showed that this weakness in perceptual grouping is a result of spatial impairment because visual abilities when dissociated from spatial relations, is preserved (Vicari et al., 2003; Farran, 2005). Other findings regarding visual abilities include strength in face recognition and judgment of emotional expressions (Bellugi et al., 2000). The ease in performing musical tasks favors learning as it increases attention span, which is frequently reduced in WBS individuals (Levitin et al., 2004).

Oral language and reading abilities

Studies of language abilities in WBS have yielded conflicting results (Chart 2). The so called dissociation between abilities (execution $\mathrm{x}$ verbal) has been questioned. According to some authors, different methods could yield variable performance patterns depending on the complexity of the task (Gosch et al., 1994; Karmiloff-Smith et al., 1998).

Receptive vocabulary in WBS, as assessed by the Peabody Test, has been considered to be adequate for mental age (Ewart et al., 1993; Mervis et al., 1999). However, others advocate that a good receptive vocabulary is not enough for a good semantic performance. The difficulty in lexical selection during linguistic tasks, such as narratives, has been pointed out, and characterizes loss of verbal fluency (Bellugi et al., 2001; KarmiloffSmith et al., 2003; Reilly et al., 2004). Oral narratives frequently display prosodic strength amid sound effects and exclamative phrases (Gonçalves et al., 2004).

Pragmatic skills have been poorly addressed in studies of WBS, although they seem to be of significant importance in the understanding of the language difficulties experienced by affected individuals. WBS individuals very frequently produce narratives that, although grammatically correct, lack coherence. The amount of speech, or number of communication acts used by WBS individuals do not respond for the social use of language (Laws and Bishop, 2004). Sociability and verbosity may be better related to the use of oral language as a communication resource rather than to competence in language abilities (Carrasco et al., 2005). Rossi et al. (2005) found deficits in semantic coherence and logic/chronologic organization of events in WBS.

Some studies have shown that WBS individuals had an adequate performance in the Digit Span test (Mervis et al., 1999) and point out that children with WBS display slightly impaired lexical-semantic and morphosyntactic abilities (Wang and Bellugi, 1994; Karmiloff-Smith et al., 1998), though with a significant difficulty in the long-term storage of information.

The visuomotor difficulties experienced by WBS individuals are associated with weakness in writing, which is frequently more affected than reading (Udwin et al., 1987). A longitudinal study of cognitive abilities and educational attainment indicated that the development of reading, spelling and arithmetic skills is quite compromised, being more favorable over the first school years and making little progress beyond that (Udwin et al., 1996).

Investigations of the contribution of phonological and semantic processes to verbal span in WBS children have suggested an impaired contribution of the lexical semantic resources to verbal span, that is, a reduced frequency effect. In fact, in tasks calling for reproducing lists of words of different frequency, normal children repeated much better the high-frequency than the lowfrequency word list (Vicari et al., 1996). In a study of phonological awareness, Majerus et al., (2001) found that WBS children were more impaired than their controls in rhyme detection and phoneme manipulation. Levy et al., (2003) found no correlation between reading and rhyme tasks, whereas word segmentation significantly correlated with the ability to read non-words. In addition, they reported that the ability to judge separate phonemes of a given word and non-word, and performance on measures of letters and word decoding were especially correlated.

Studies of language skills have yielded conflicting results. The oral language abilities in WBS have been more frequently described than writing skills. Even the studies focusing on oral language have poorly addressed pragmatic abilities and the use of communicative resources by WBS individuals within several communicative contexts. 
FIGURE 1A. Chromosome 7 ideogram showing the 7q11.23 region deleted in WBS

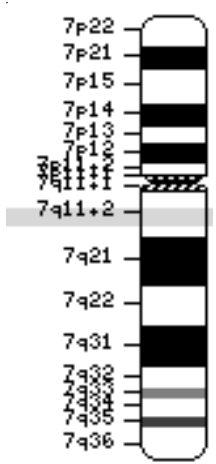

FIGURE 1B. FISH test used in the cytogenetic-molecular diagnosis of WBS. Notice the absence of the red sign (arrow) in one of the chromosomes 7 , confirming the deletion of the ELN gene.

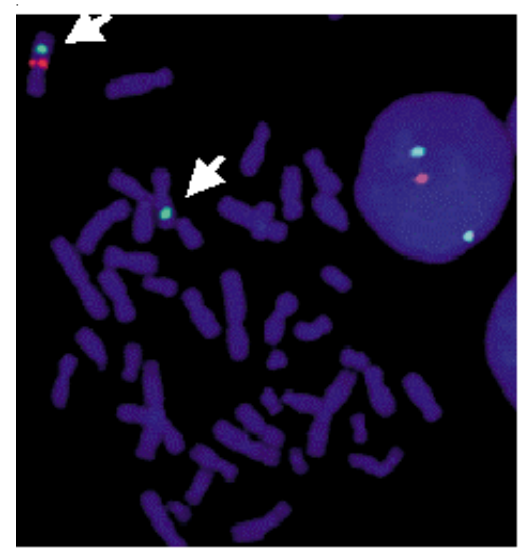

FIGURE 2. Facial aspect of 4 WBS individuals with deletion of the ELN gene detected by FISH at the Genetic Counseling Service, Institute of Biosciences/ UNESP-Botucatu, SP.

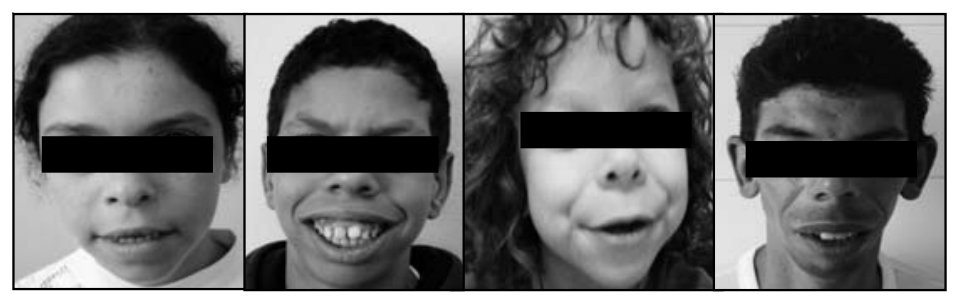


CHART 1. Frequency of clinical signs in the literature reviewed (Borg et al., 1995; Kotzot et al., 1995; Lowery et al., 1995; Nickerson et al., 1995; Joyce et al., 1996; Perez-Jurado et al., 1996; Elçoglu et al., 1998; Beust et al., 2000; Mila et al., 2000; Sugayama, 2001; Souza, 2003).

\begin{tabular}{|c|c|c|}
\hline \multirow{2}{*}{ Clinical Manifestations } & with microdeletion & Without microdeletion \\
\hline & $\mathrm{Np} / \mathrm{Ni}(\%)$ & Np / Ni (\%) \\
\hline \multicolumn{3}{|l|}{ At birth/ early childhood } \\
\hline Failure to thrive & $202 / 218(92,6)$ & $45 / 58(77,5)$ \\
\hline Low birthweight & $42 / 61(68,8)$ & $8 / 44(18,1)$ \\
\hline Difficulty in gaining weight & $40 / 70(57,1)$ & $16 / 37(43,2)$ \\
\hline Low stature & $37 / 94(39,3)$ & $6 / 22(27,2)$ \\
\hline Instestinal constipation & $39 / 60(65,0)$ & $10 / 37(20,0)$ \\
\hline Recurrent otitis & $4 / 14(28,5)$ & $0 / 3(0,0)$ \\
\hline Hypercalcemia & 44/197 (22,3) & $9 / 41(21,9)$ \\
\hline Inguinal/ umbilical hernia & $65 / 179(36,3)$ & $5 / 14(35,7)$ \\
\hline \multicolumn{3}{|l|}{ Facial characteristics } \\
\hline Periorbital fullness & $241 / 260(92,6)$ & $22 / 56(39,2)$ \\
\hline Full cheeks & $236 / 274(86,1)$ & $27 / 57(47,3)$ \\
\hline Low nasal bridge & $156 / 175(89,1)$ & $21 / 23(91,3)$ \\
\hline Anteverted nostrils & 216/235 (91,9) & $18 / 47(38,2)$ \\
\hline Long nasal philtrum & $228 / 252(90,4)$ & $18 / 50(36)$ \\
\hline Wide mouth & 253/271 (93,3) & $25 / 58(43,1)$ \\
\hline Full lips & $218 / 227(96,0)$ & $21 / 43(48,8)$ \\
\hline Dental anomalies & $60 / 93(64,5)$ & $18 / 53(33,9)$ \\
\hline Big anteverted ears & $7 / 15(46,6)$ & $1 / 3(33,3)$ \\
\hline \multicolumn{3}{|l|}{ Cardiovascular characteristics } \\
\hline Cardiovascular disorders (supravalvular aortic stenosis and pulmonary artery sclerosis) & $306 / 470(65,1)$ & $22 / 167(13,1)$ \\
\hline Systemic hypertension & $16 / 128(12,5)$ & $0 / 42(0,0)$ \\
\hline \multicolumn{3}{|l|}{ Ophtalmological characteristics } \\
\hline Strabismus & $39 / 76(51,3)$ & $2 / 17(11,7)$ \\
\hline Stellate íris & $25 / 72(34,7)$ & $3 / 16(18,7)$ \\
\hline \multicolumn{3}{|l|}{ Muscle-skeleton characteristics } \\
\hline Clinodactyly of the 5th finger & $35 / 65(53,8)$ & $22 / 42(52,3)$ \\
\hline Renal disorders & $18 / 91(19,7)$ & $1 / 16(6,5)$ \\
\hline \multicolumn{3}{|l|}{ Personality, cognition, language and hearing characteristics } \\
\hline Mental retardation & $187 / 210(89,0)$ & $51 / 77(66,3)$ \\
\hline Friendliness & 78/93 $(83,8)$ & $29 / 78(37,1)$ \\
\hline Anxiety & $24 / 37(64,8)$ & $5 / 8(62,5)$ \\
\hline Hyperactivity & $35 / 51(68,3)$ & $7 / 12(58,3)$ \\
\hline Loquacity & 29/52 (55,7) & $1 / 10(10,0)$ \\
\hline Hyperacusia & $27 / 55(49,0)$ & $2 / 13(15,3)$ \\
\hline Hoarse voice & 25/32 (78,1) & $21 / 77(27,2)$ \\
\hline
\end{tabular}

Legend: $\mathrm{Np}$ =number of subjects with clinical sign present; $\mathrm{Ni}=$ number of subjects investigated for the clinical sign. 
CHART 2. Reviewed studies that focused on aspects related to cognition and language/learning abilities.

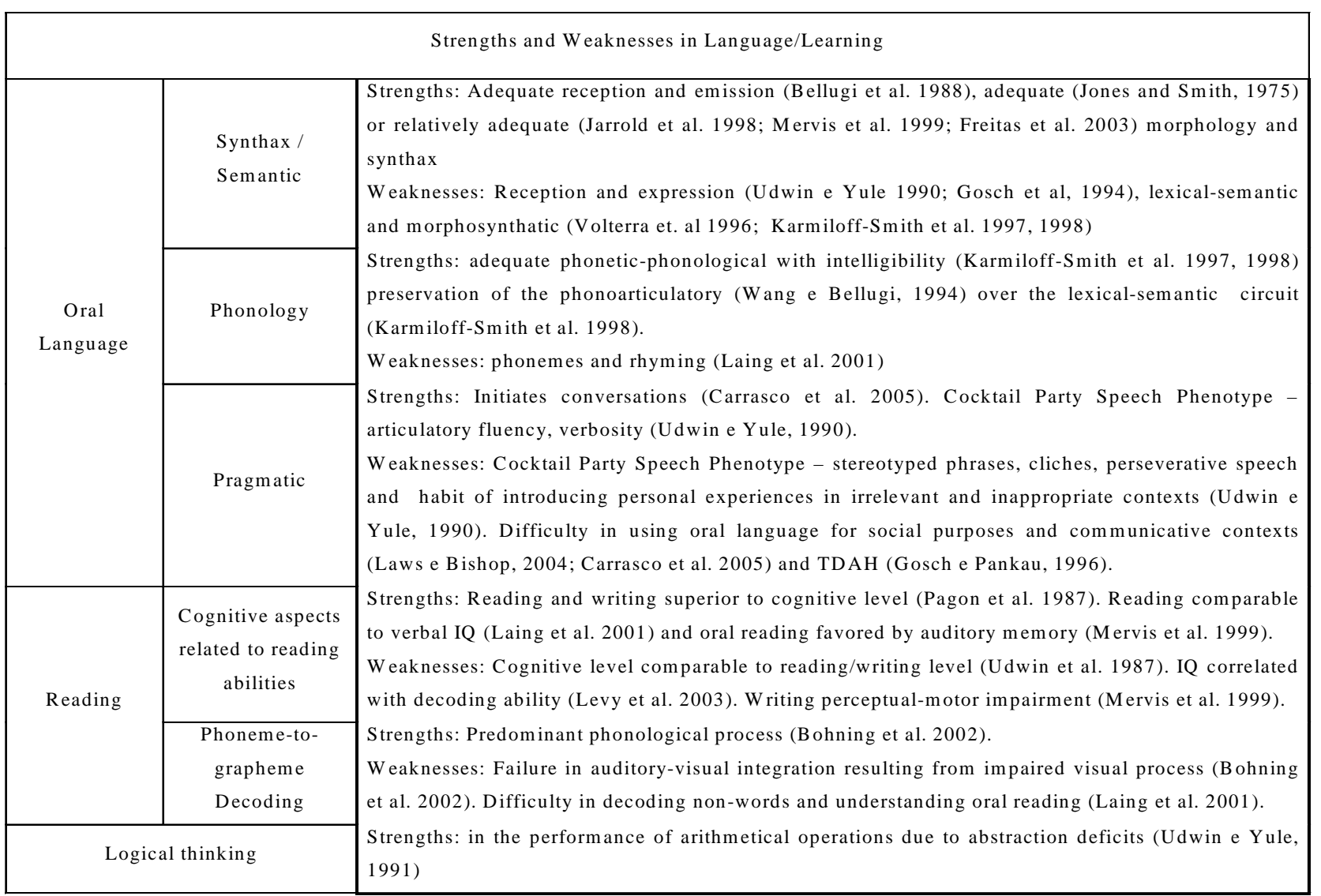

\section{Conclusion}

Studies of language abilities in WBS are still scarce considering the number of genetic and cognitive studies conducted over the past 5 years.

The literature reviewed about the genetic aspects of cognition and language in WBS showed that the etiology of this genetic condition is known, but early diagnosis may be hindered by the variability in clinical manifestations, especially in the absence of cardiac abnormalities or symptoms. The clinical phenotype includes remarkable characteristics of personality, compromised cognition and language, which associated with physical features, could allow the clinical diagnosis of this condition and indicate the performance of the FISH test by a geneticist.

The studies reviewed reported interesting results that justify the recognition of a peculiar neuron-cognitive profile phenotype of WBS and point out to the hypothesis of dissociation between cognition and language abilities. This hypothesis was supported by the studies that reported relatively preserved language abilities and weakness in cognition. This was not corroborated by all investigators, who demonstrated linguistic deficits in oral narrative tasks that allowed the identification of pragmatic impairment. Unfortunately, the national literature reviewed revealed a shortage of studies focusing cognition and language problems in WBS.

Studies devoted to the characterization of the neuron-cognitive and linguistic phenotype in this syndrome, associated with molecular studies, may bring, in a near future, benefits to the patients and their families, given that the information obtained may be helpful for the conduction of genetic counseling and interventions for these clinical manifestations, including communication aspects.

These findings might also improve the understanding of mechanisms related to the personality traits, cognition and language from the standpoint of genetics not only in WBS individuals, but in the whole humankind. 


\section{References}

BELLUGI, U.; BIHRLE, A.; TRAUNER, D.; DOHERTY, S. Neuropsychological, neurological and neuroanatomical profile of Williams syndrome. Am. J. Med. Genet., New York, v. 6, p. 115-125, 1988. suppl. 1.

BELLUGI, U.; WANG, P. P.; JERNINGAN, T. L. William's syndrome: an unusual neuropsycological profile. In: BROMAN, S. H.; GRAFMAN, J. Atypical cognitive deficits in developmental disorders: implication for brain function. Hisdale (NJ): Erlbaum, 1994. p. 23-56.

BELLUGI, U.; ADOLPHS, R.; CASSADY, C.; CHILES, M. Towards the neural basis for hypersociability in a genetic syndrome. Neuroreport., London, v. 10, n. 8, p. 1653-1657, june 1999.

BELLUGI, U.; LICHTENBERGER, L.; JONES, W.; LAI, Z. S. T.; GEORGE, M. The neurocognitive profile of Williams syndrome: a complex pattern of strengths and weaknesses. $J$. Cogn. Neurosci., Cambridge, v. 1, p. 7-29, 2000. suppl. 12.

BELLUGI, U.; KORENBERG, J. E.; KLIMA, E. S. Williams syndrome: an exploration of neurocognitive and genetic features. Clin. Neur. Res., California, v. 1, n. 3, p. 217-229, may 2001.

BEUREN, A. J. Supravalvular aortic stenosis: a complex syndrome with and without mental retardation. Birth Defects Art. Ser., New York, v. 8, n. 5, p. 45-56, 1972. apud: WILLIAMS. Beuren syndrome. Online Mendelian Inheritance Men (OMIM), s.d. Disponível em: <http:// www.ncbi.nlm.nih.gov/entrez/dispomim.cgi?id=194050>. Acesso em: 22 maio 2005.

BEUST, A. J.; LACCONE, F. A.; DEL PILAR, A. M.; WESSEL, A. Clinical aspects and genetics of Williams-Beuren syndrome. Klin Padiatr., Stuttgart, v. 212, n. 2, p. 299307, nov.-dec. 2000.

BORG, I.; DELHANTY, J. D. A.; BARAITSER, M. Detection of hemizygosity at the elastin locus by FISH analysis as a diagnostic test in both classical and atypical cases of Williams syndrome. J. Med. Genet., London, v. 32, n. 9, p. 692-696, sept. 1995.

CARRASCO, X.; CASTILHO, S.; AVARENA, T.; ROTHHAMMNER, P. Williams syndrome: pediatric, neurologic and cognitive development. Pediatric. Neurology., New York, v. 32, n. 3, p. 166-172, mar. 2005.

ELÇIOGLU, N.; MACKIE-OGILVIE, C.; DAKER, M.; BERRY, A. C. Fish analysis in patients with clinical diagnosis of Williams syndrome. Acta Paediatr., Oslo, v. 87, n. 1, p. 48-53, jan. 1998.

EWART, A. K.; MORRIS, C. A.; ATKINSON, D.; JIN, W.; STERNES, K.; SPALLONE, P.; STOCK, A. D.; LEPPERT, M.; KEATING, M. T. Hemizygosity at the elastin locus in a developmental disorder Williams syndrome. Nature Genet., New York, v. 5, n. 1, p. 11-16, sept. 1993.

FARRAN, E. K.; JARROLD, C. Visuospatial cognition in Williams syndrome: reviewing and accounting for the strengths and weaknesses in performance. Dev. Neuropsychol., Mahwah, v. 23, n. 1 e n. 2, p. 173-200, 2003.

FARRAN, E. K. Perceptual grouping ability in Williams syndrome: evidence for deviant patterns of performance. Neuropsychol., Oxford, v. 43, n. 5, p. 815-822, 2005.
FREITAS, M. C.; SILVEIRA, M. S.; CORRÊA, L. M. S. Seletividade no desempenho lingüístico de portadores da síndrome de Williams e do déficit especificamente lingüístico (DEL). In: CONGRESSO INTERNACIONAL DA ASSOCIAÇÃO BRASILEIRA DE LINGÜÍSTICA (ABRALIN). 3., 2003, Rio de Janeiro. Anais... Rio de Janeiro: PUC, 2003. p. 10-19.

GOSCH, A.; STADING, G.; PANKAU, R. Linguistic abilities in children with Williams-Beuren syndrome. Am. J. Med. Genet., New York, v. 52, n. 3, p. 291-296, sept. 1994.

GOSCH, A.; PANKAU, R. Longitudinal study of the cognitive development in children with Williams-Beuren syndrome. Am. J. Med. Genet., New York, v. 61, n. 1, p. 26-29, jan. 1996.

GONÇALVEZ, O. F.; PÉREZ, A.; HENRIQUES, M.; PRIETO, M.; LIMA, M. R.; SIEBERT, M. F.; SOUSA, N. Funcionamento cognitivo e produção narrativa no síndrome de Williams: congruência ou dissociação neurocognitiva? Int. J. Clin. Health. Psychol., Granada, v. 4, n. 3, p. 623638, 2004.

JARROLD, C.; BADDLEY, A. D.; HEWES, A. K. Verbal and noverbal abilities in the Williams syndrome phenotype: evidence for diverging developmental trajectories. J. Child Psychol. Psychiatry., London, v. 39, n. 4, p. 511-523, may 1998.

JARROLD, C.; BADDLEY, A. D.; HEWES, A. K. Genetically dissociation components of working memory: evidence from Down's syndrome and Williams syndrome. Neuropsychol., Oxford, v. 37, n. 6, p. 637-651, june 1999.

JONES, K. L.; SMITH, D. W. The Williams elfin facies syndrome. J. Pediatr., St. Louis, v. 86, n. 5, p. 718-723, may 1975.

JOYCE, C. A.; ZORICH, B.; PIKE, S. J.; BARBER, J. C. K.; DENNIS, N. R. Williams-Beuren syndrome: phenotypic variability and deletions of chromosomes 7, 11, and 22 in a series of 52 patients. J. Med. Genet., London, v. 33, n. 12, p. 986-992, dec. 1996.

JORDAN, H.; REISS, J. E.; HOFFMAN, J. E.; LANDA, U. B. Intact perception of biological motion in the face of profound spatial deficits: Williams syndrome. Psychol Sci., Malden, v. 13, n. 2, p. 162-167, mar. 2002.

JOSEPH, M. C.; PARROT, D. Severe infantile hypercalcemia with special reference to the facies. Arch. Dis. Child., London, v. 33, n. 171, p. 385-395, oct. 1958.

KARMILOFF-SMITH, A.; GRANT, J.; BERTHOUD, I.; DAVIES, M.; HOWLIN, P.; UDWIM, O. Language and Williams syndrome: how intact is "intact"? Chil. Develop., Malden, v. 68, n. 2, p. 246-262, apr. 1997.

KARMILOFF-SMITH, A.; TYLER, L. K.; VOICE, K.; SIMS, K.; UDWIN, O.; HOWLIN, P.; DAVIES, M. Linguistic dissociations in Williams syndrome: evaluating receptive syntax in on-line and off-line tasks. Neuropsychol., Oxford, v. 36, n. 4, p. 343-351, apr. 1998.

KAMIRLOFF-SMITH, A.; BROWN, J.; GRICE, S. E.; PATERSON, S. Dethroning the myth: cognitive dissociations and innate modularity in Williams syndrome. Develop. Neuropsych., Mahwah, v. 23, n. 1 e n. 2, p. 227242, 2003. 
KOTZOT, D.; BERNASCONI, F.; BRECEVIC, L.; ROBINSON, W. P.; KISS, P.; KOSZTOLANI, G. Phenotype of the Wlliams-Beuren syndrome associated with hemizygosity at the elastin locus. Eur. J. Pediatr., Berlin, v. 154, n. 6, p. 477-482, june 1995.

LAING, E.; HULME, C.; GRANT, J.; KARMILOFFSMITH, A. Learning to read in Williams syndrome: looking beneath the surface of atypical reading development. J. Child. Psychol. Psychiatry., London, v. 42, n. 6, p. 729-739, sept. 2001.

LAWS, G.; BISHOP, D. Pragmatic language impairment and social deficits in Williams syndrome: a comparison with Down's syndrome and specific language impairment. Int. J. Lang. Commun. Disord., London, v. 39, n. 1, p. 45-64, jan.-mar. 2004.

LEVITIN, D. J.; COLE, K.; CHILES, M.; LAI, Z.; LINCOLN, A.; BELLUGI, U. Characterizing the musical phenotype in individuals with williams syndrome. Child. Neuropsychol., Philadelphia, v. 10, n. 4, p. 223-247, dec. 2004.

LEVY, Y.; SMITH, J.; TAGER-FLUSBERG, H. Word reading and reading-related skills in adolescents with Williams syndrome. J. Child. Psychiatry., Oxford, v. 44, n. 4, p. 576-587, may 2003.

LOWERY, M. C.; MORRIS, C. A.; EWART, A. K.; BROTHMAN, L. J.; ZHU, X. L.; LEONARD, C. O. Strong correlation of elastin deletions, detected by FISH, with Williams syndrome: evaluation of 235 patients. Am. J. Hum. Genet, Chicago, v. 57, n. 1, p. 49-53, jul. 1995.

MAJERUS, S.; PALMISANO, I.; VAN DER LINDEN, M.; BARISNIKOV, K.; PONCELET, M. An investigation of phonological processing in Williams syndrome. In: ANNUAL INS MEETING. 29., 2001, London. Abstracts. Cambrige: Cambrige University Press. 2001. p. 153.

MERVIS, C. B.; MORRIS, C. A.; BERTRAND, J.; ROBINSON, B. F. Williams syndrome: findings from an integrated program of research. In: TAGER-FLSUBERG, H. (Ed.). Neurodevelopmental disorders. Boston: Mit Press, 1999. p. 65-110. apud: LEVY, Y.; SMITH, J.; TAGERFLUSBERG, $\mathrm{H}$. Word reading and reading-related skills in adolescents with Williams syndrome. J. Child. Psychol. Psychiatry, London, v. 44, n. 4, p. 576-587, may 2003.

MERVIS, C. B.; KLEIN-TASMAN, B. P. Williams syndrome: cognition, personality, and adaptive behavior. Ment. Retard. Dev. Disabil. Res. R., New York, v. 6, n. 2, p. 148-158, 2000.

MILA, M.; CARRIO, A.; SANCHEZ, A.; GOMEZ, D.; JIMENEZ, D.; ESTIVILL, X.; BALLESTA, F. Clinical characterization, molecular and FISH studies in 80 patients with clinical suspicion of Williams-Beuren syndrome. Med. Clin., Barcelona, v. 113, n. 2, p. 46-49, jun. 1999.

MONTGOLFIER-AUBRON, I.; BURGLEN, L.; CHAVET, M. S.; TEVISSEN, H.; PERROT, C.; BAUDON, J. J.; GOLD, F. Early revealing of Williams-Beuren syndrome by digestive disorders. Arch Pediatr., Barcelona, v. 7, n. 10, p. 1085-1087, oct. 2000.

NICKERSON, E.; GREENBERG, F.; KEATING, M. T.; MCCASKILL, C.; SHAFFER, L. G. Deletions of the elastin gene at $7 \mathrm{q} 11.23$ occur in approximately $90 \%$ of patients with Williams syndrome. Am. J. Hum. Genet., Chicago, v. 56, n. 5, p. 1156-1161, may 1995.
PAGON, R. A.; BENNET, F. C.; LAVECK, B.; STEWART, K. B.; JOHNSON, J. Williams syndrome: features in late childhood and adolescence. Pediatrics., Philadelphia, v. 80, n. 1, p. 85-91, july 1987.

PANKAU, R.; PARTSCH, C. J.; NEBLUNG, A.; GOSH, A.; WESSEL, A. Head circunference of children with Williams-Beuren syndrome. Am. J. Med. Genet., New York, v. 52, n. 3, p. 285-290, sept. 1994.

PEREZ-JURADO, L. A.; PEOPLES, R.; KAPLAN, P.; HAMEL, B. C. J.; FRANCKE, U. Molecular definition of the chromosome 7 deletion in Williams syndrome and parent-of-origin effects on growth. Am. J. Hum. Genet., Chicago, v. 59, n. 4, p. 781-792, oct. 1996.

PORTER, M. A.; COLTHEART, M. Cognitive heterogeneity in williams syndrome. Dev. Neuropsychol., Mahwah, v. 27, n. 2, p. 275-306, 2005.

REILLY, J.; LOSH, M.; BELLUGI, U.; WULFECK, B. "Frog, where are you ?": narratives in children with specific language impairment, early focal brain injury and Williams syndrome. Brain Lang., Orlando, v. 88, n. 2, p. 229-247, feb. 2004.

ROSSI, N. F.; PEREIRA, V. M.; PEROSA, G. B.; GOMES, T. C. G.; GIULIANI, L. R.; SOUZA, D. H.; MORETTIFERREIRA, D.; GIACHETI, C. M. Habilidades psicolingüísticas auditivas e visuais na síndrome de WilliamsBeuren. In: CONGRESSO BRASILEIRO DE GENÉTICA CLÍNICA, 17., 2005, Curitiba (PR). Anais... Curitiba: Sociedade Brasileira de Genética, 2005.

SOUZA, D. H. Estudo citogenético da região 7q11.23: a síndrome de Williams-Beuren. 2003. 150 f. Tese (Doutorado em Pediatria) - Faculdade de Medicina, Universidade Estadual Paulista, São Paulo.

SUGAYAMA, S. M. M. Estudo genético-clínico $e$ citogenética molecular pela técnica da hibridação in situ por fluorescência (FISH) em pacientes com síndrome de Williams-Beuren. 2001. 153 f. Tese (Doutorado em Pediatria) - Faculdade de Medicina, Universidade de São Paulo, São Paulo.

UDWIN, O.; YULE, W.; MARTIN, N. Cognitive abilities and behavioral characteristics of children with idiopathic infantile hypercalcemia. J. Child. Psychol. Psychiatry., London, v. 28, n. 2, p. 297-309, mar. 1987.

UDWIN, O.; YULE, W. Expressive language of children with Williams syndrome. Am. J. Med. Geneti., New York, v. 6, p. 108-114, 1990. suppl. 1.

UDWIN, O.; YULE, W. A cognitive and behavioural phenotype in Williams syndrome. J. Clin. Exper. Neuropsychol., Lisse, v. 2, n. 2, p. 232-242, mar. 1991.

UDWIN, O.; DAVIES, M.; HOWLIN, P. A longitudinal study of cognitive abilities and educational attainment in Williams syndrome. Dev. Med. Child. Neurol., London, v. 38, n. 11, p. 1020-1029, nov. 1996.

VICARI, S.; BELLUCCI, S.; CARLESIMO, G. A. Visual and spatial working memory dissociation: evidence from Williams syndrome. Dev. Med. Child. Neurol., London, v. 45, n. 4, p. 269-273, apr. 2003.

VICARI, S.; CARLESIMO, G.; BRIZZOLARA, D.; PEZZINO, G. Short term memory in children with Willians syndrome: a reduced contribution of lexical-semantic knowledge to word span. Neuropsychol., Oxford, v. 34, n. 9, p. 919-925, sep. 1996. 
VOLTERRA, V.; CAPIRCI, O.; PEZZINI, G.; SABBATDINI, L.; VICARI, S. Linguistic abilities in Italian children with Williams syndrome. Córtex., Milan, v. 32, n. 4, p. 663-677, dec. 1996.

WANG, P. P.; BELLUGI, U. Evidence from two genetic syndromes for a dissociation between verbal and visualspatial short-term memory. J. Clin. Exp. Neuropsychol., Lisse, v. 16, n. 2, p. 317-322, apr. 1994. apud: VICARI, S.; BELLUCCI, S.; CARLESIMO, G. A. Procedural learning deficit in children with Williams syndrome. Neuropsychol., Oxford, v. 39, n. 7, p. 665-677, 2001.

WILLIAMS. Beuren syndrome. Online Mendelian Inheritance Men (OMIM), s.d. Disponível em: <http:// www.ncbi.nlm.nih.gov/entrez/dispomim.cgi?id=194050>. Acesso em: 22 maio 2005.

WILLIAMS, J. C.; BARRATT-BOYES, B. G.; LOWE, J. B. Supravalvular aortic stenosis. Circulation., Hagerstown, v. 24, n. 6, p. 1311-1318, dec. 1961. 